\title{
Interaction between BDNF Val66Met and Dopamine Transporter Gene Variation Influences Anxiety-Related Traits
}

\author{
Regina Hünnerkopf ${ }^{1,3}$, Alexander Strobel ${ }^{2,3}$, Lise Gutknecht', Burkhard Brocke ${ }^{2}$ and Klaus Peter Lesch*,I \\ 'Molecular and Clinical Psychobiology, Department of Psychiatry and Psychotherapy, University of Würzburg, Würzburg, Germany; ${ }^{2}$ Differential \\ and Personality Psychology, Institute of Psychology II, University of Technology, Dresden, Germany
}

\begin{abstract}
The involvement in neural plasticity and the mediation of effects of repeated stress exposure and long-term antidepressant treatment on hippocampal neurogenesis supports a critical role of brain-derived neurotrophic factor (BDNF) in the pathophysiology of affective and other stress-related disorders. A previously reported valine to methionine substitution at amino-acid position 66 (BDNF Val66Met) seems to account for memory disturbance and hippocampal dysfunction. In the present study, we evaluated the impact of the BDNF Val66Met polymorphism on individual differences in personality traits in a sample of healthy volunteers in relation to other common gene variants thought to be involved in the pathophysiology of affective disorders, such as the serotonin transporter promoter polymorphism (5-HTTLPR) and a variable number of tandem repeat polymorphism of the dopamine transporter gene (DAT VNTR). Personality traits were assessed using the NEO personality inventory (NEO-PI-R) and Tridimensional Personality Questionnaire (TPQ). There was a significant DAT VNTR-dependent association between NEO-PI-R Neuroticism and the BDNF Val66Met polymorphism. Among individuals with at least one copy of the DAT 9-repeat allele, carriers of the BDNF Met allele exhibited significantly lower Neuroticism scores than noncarriers. This interaction was also observed for TPQ Harm Avoidance, a personality dimension related to Neuroticism. Our results support the notion that allelic variation at the BDNF locus - in interaction with other gene variants - influences anxietyand depression-related personality traits.

Neuropsychopharmacology (2007) 32, 2552-2560; doi:I 0.I038/sj.npp. I 30I383; published online 28 March 2007
\end{abstract}

Keywords: BDNF; DAT; polymorphism; neuroticism; anxiety- and depression-related traits; association

\section{INTRODUCTION}

Brain-derived neurotrophic factor (BDNF) is involved in a variety of trophic and modulatory effects that include an essential function in the development and plasticity of dopaminergic, serotonergic, and other neurons (Bonhoeffer, 1996; Lu and Chow, 1999; Poo, 2001). Reduced expression of BDNF modifies synaptic plasticity resulting in specific alterations in spatial learning and memory processes, anxiety-related behavior, and motor activity in the knockout mouse model (McAllister et al, 1999; Kernie et al, 2000; Carter et al, 2002; Tyler et al, 2002; Yamada et al, 2002). However, targeted inactivation of the BDNF receptor, TrkB, leads to neuronal loss and cortical degenerative changes (Vitalis et al, 2002; Xu et al, 2000). In addition, BDNF mediates the effects of repeated stress exposure and longterm antidepressant treatment on neurogenesis and neuro-

*Correspondence: Dr KP Lesch, Molecular and Clinical Psychobiology, Department of Psychiatry and Psychotherapy, University of Würzburg, Füchsleinstr. 15, 97080 Würzburg, Germany, Tel: + 49 93। 201 77600, Fax: + 49931201 77620, E-mail: kplesch@mail.uni-wuerzburg.de

${ }^{3}$ These authors contributed equally to this work.

Received 29 September 2006; revised I I December 2006; accepted 7 January 2007 nal survival in the hippocampus (D'Sa and Duman, 2002; Rasmusson et al, 2002). These findings converge with impaired hippocampal plasticity in depression reflected by a reduced hippocampal volume and hippocampus-related memory deficiency, which supports that BDNF plays a critical role in the pathophysiology of affective and other stress-related disorders (Duman et al, 1997, 2001; Garcia, 2002; Hull, 2002; McEwen and Magarinos, 2001).

In fact, the experience of stressful life events is neither necessary nor sufficient for the development of depression or anxiety disorders. Liability to these disorders is, therefore, more likely to arise from a complex interaction of stress exposure with a variety of vulnerability factors including anxiety-related personality traits, such as Neuroticism (Costa and McCrae, 1992; Eysenck and Eysenck, 1985), Harm Avoidance (Cloninger, 1987), or Negative Emotionality (Watson and Tellegen, 1985). The spectrum of these higher-order personality traits refers to a basic concept comprising lower-order traits like stress reactivity, anxiety, depressiveness, or hostility. The finding that approximately $55 \%$ of the genetic liability of major depression is shared with Neuroticism (Kendler et al, 1993) renders it plausible that some of the same genes that modulate the disposition to depression also affect individual differences in anxiety-related traits. 
Sen et al (2003) reported the association between Neuroticism and a valine to methionine substitution at amino-acid position 66 (BDNF Val66Met) located in the $\mathrm{N}$-terminal sequence upstream of the mature BDNF protein. Individuals with the rare BDNF Met/Met genotype showed significantly lower Neuroticism scores, which led to the conclusion that the Val allele may increase the risk for anxiety and depression spectrum disorders. This notion is further supported by several recent familybased studies revealing a preferential transmission of the BDNF Val allele to bipolar individuals (Neves-Pereira et al, 2002; Sklar et al, 2002; Geller et al, 2004; Lohoff et al, 2005).

The aim of our study was, therefore, to confirm the association between the BDNF Val66Met polymorphism and Neuroticism, and furthermore, to explore possible interactions of this polymorphism with other common gene variants thought to be involved in the pathophysiology of stress-related and affective disorders. Based on the evidence of a reciprocal modulatory interaction of BDNF, serotonin, and dopamine (Vollmayr et al, 2000; Goggi et al, 2002; Canals et al, 2001; Küppers and Beyer, 2001), and of this interaction in the pathophysiology of depression (Meltzer, 1990; Willner et al, 1991) and stress disorders (Vermetten and Bremner, 2002), we focused specifically on the variation in genes influencing the functionality of the serotonergic and dopaminergic system. Hence, interaction effects of the BDNF Val66Met polymorphism were investigated with the length variation in the transcriptional control region of the serotonin transporter (5-HTT, SLC6A4) gene (5-HTT linked polymorphic region, 5-HTTLPR) and with the variable number of tandem repeat polymorphism in the $3^{\prime}$ untranslated region of the dopamine transporter gene SLC6A3 (DAT VNTR), which both have previously been reported to modify expression of the respective gene. 5-HTTLPR seems to play a role in the modulation of Neuroticism (Lesch et al, 1996; Greenberg et al, 2000) and in several neuropsychiatric disorders including affective disorders (Lesch, 2001). Furthermore, serotonin transporter function was demonstrated as being influenced by BDNF in a 5-HTTLPR genotype-dependent fashion (Mössner et al, 2000). The DAT VNTR has been less intensively investigated, although it had been reported previously as being associated with post-traumatic stress disorder (PTSD) (Segman et al, 2002). It seems, therefore, reasonable to examine potential interactive influences of these polymorphisms and BDNF on individual differences in Neuroticism and related personality traits.

\section{PARTICIPANTS AND METHODS}

\section{Participants and Procedures}

Two hundred seventy-two healthy volunteers of German ethnicity (203 females and 69 males; mean age: $21.9 \pm 3.8$ years, age range: 18-41 years) were recruited from the student body and staff at the Dresden University of Technology. The study was carried out in accordance with the Declaration of Helsinki. All participants gave written informed consent, and $200 \mu \mathrm{l}$ of blood from earlobes was obtained. Participants completed the German versions of the Revised NEO Personality Inventory (NEO-PI-R; Ostendorf and Angleitner, 2003) and the Tridimensional Personality Questionnaire (TPQ; Weyers et al, 1995). The NEO$\mathrm{PI}-\mathrm{R}$ is based on the five-factor model of personality (Costa and McCrae, 1992). It consists of 241 Likert-type items and assesses individual differences in 30 personality facets, which can be aggregated to the five personality factorsNeuroticism, Extraversion, Openness to Experience, Agreeableness, and Conscientiousness. The TPQ is based on Cloninger's neurobiological theory of personality (Cloninger, 1987). Its 100 items assess individual differences along the temperament dimensions: Novelty Seeking, Harm Avoidance, and Reward Dependence. Each of the three temperament scales is comprised of four subscales, the Reward Dependence subscale Persistence mostly being considered as a separate fourth temperament factor (Cloninger et al, 1993). The German versions of the NEOPI-R and the TPQ exhibit acceptable psychometric properties (Ostendorf and Angleitner, 2003; Weyers et al, 1995).

\section{Genotyping}

DNA was extracted from EDTA blood using the QIAamp Blood Kit (Qiagen, Hilden, Germany).

For the $B D N F$ gene, the $\mathrm{G} \rightarrow \mathrm{A}$ single nucleotide polymorphism (SNP) coding for the Val66Met substitution was genotyped following a modified protocol by Sen et al (2003) and Mössner et al (2005). A 274-bp polymerase chain reaction (PCR) product containing the SNP was amplified by PCR using the following reaction mix: $20 \mathrm{ng}$ of genomic DNA in $75 \mathrm{mM}$ Tris- $\mathrm{HCl}(\mathrm{pH} 9.0), 20 \mathrm{mM}$ ammonium sulfate, $0.01 \%$ Tween $20,1.5 \mathrm{mM}$ magnesium chloride, $0.4 \mu \mathrm{M}$ of each of the primers, BDNF-for (5'-AAA GAA GCA AAC ATC CGA GGA CAA G) and BDNF-rev (5'-ATT CCT CCA GCA GAA AGA GAA GAG G), $0.4 \mathrm{mM}$ dNTP, and $1 \mathrm{U}$ Taq polymerase. After an initial denaturation for $5 \mathrm{~min}$ at $95^{\circ} \mathrm{C}, 35$ cycles of denaturating at $95^{\circ} \mathrm{C}$ for $30 \mathrm{~s}$, annealing at $55^{\circ} \mathrm{C}$ for $40 \mathrm{~s}$, and extension at $72^{\circ} \mathrm{C}$ for $50 \mathrm{~s}$ were performed, followed by a final extension at $72^{\circ} \mathrm{C}$ for $5 \mathrm{~min}$. PCR products were digested with NlaIII. The undigested PCR product carries the A variant, whereas the digested product with three fragments of 57,77 , and $140 \mathrm{bp}$ contains the $\mathrm{G}$ allele.

For the DAT gene, the 40-base-pair VNTR located in the 3 '-untranslated region of the DAT cDNA was amplified from genomic DNA using $5 \mathrm{U}$ of Taq DNA polymerase. After an initial denaturation for $3 \mathrm{~min}$ at $95^{\circ} \mathrm{C}, 35$ cycles of denaturing at $93^{\circ} \mathrm{C}$ for $45 \mathrm{~s}$, annealing at $67.5^{\circ} \mathrm{C}$ for $45 \mathrm{~s}$, and extension at $72^{\circ} \mathrm{C}$ for $45 \mathrm{~s}$ were performed in the presence of primers $5^{\prime}$-TGT GGT GTA GGG AAC GGC CTG AG-3' and 5'-CTT CCT GGA GGT CAC GGC TCA AGG-3', followed by a final extension at $72^{\circ} \mathrm{C}$ for $3 \mathrm{~min}$. PCR amplification was carried out in a final volume of $25 \mu$ l consisting of $80 \mathrm{ng}$ of genomic DNA, $250 \mu \mathrm{M}$ of each deoxyribonucleotide, $10 \mathrm{pmol}$ of sense and antisense primers, $10 \mathrm{mM}$ Tris- $\mathrm{HCl}$ ( $\mathrm{pH} \mathrm{8.3),} 50 \mathrm{mM} \mathrm{KCl}$, and $1.5 \mathrm{mM} \mathrm{MgCl}_{2}$.

For the 5-HTT gene, the 5-HTTLPR was genotyped according to a previously published protocol (Lesch et al, 1996).

BDNF allele frequencies were $16.9 \%$ for the A (Met) allele and $83.1 \%$ for the $\mathrm{G}$ ( Val) allele, and BDNF genotype frequencies were $3.3 \%$ for Met/Met, $27.2 \%$ for Val/Met, and 
$69.5 \%$ for $\mathrm{Val} / \mathrm{Val}$ genotypes. 5-HTTLPR allele frequencies were $61.2 \%$ for the 1 allele and 38.4 for the $\mathrm{s}$ allele, and genotype frequencies were $36.0 \%$ for $1 / 1,50.5 \%$ for $1 / \mathrm{s}$, and $13.2 \%$ for s/s (genotype data of one participant were missing). DAT VNTR allele frequencies were $25.2 \%$ for the 9-repeat and $74.8 \%$ for the 10 -repeat, DAT VNTR genotype frequencies were $7.0 \%$ for $9 / 9,36.4 \%$ for $9 / 10$, and $56.6 \%$ for $10 / 10$ genotypes. All genotypes were in Hardy-Weinberg equilibrium ( $\chi^{2}$-tests, all $\left.p \geqslant 0.271\right)$. For subsequent statistical analyses focusing on gene-gene interactions, the BDNF, 5-HTTLPR, and DAT VNTR genotypes were dichotomized to enhance statistical power. The groups of individuals with the BDNF Met/Met and Val/Met genotypes were combined based on the Met-related impairments observed by Egan et al (2003). Likewise, 5-HTTLPR genotypes were grouped according to the presence $(\mathrm{S})$ or absence (L) of the $s$ allele by reference to the observed dominant effect of the $s$ allele (Lesch et al, 1996). DAT VNTR genotypes were dichotomized for the presence $(9+)$ or absence $(9-)$ of the DAT 9-repeat allele based on the differential DAT expression in the presence of the 9-repeat allele (Fuke et al, 2001; Mill et al, 2002).

\section{Statistical Analyses}

All analyses were carried out using SPSS 9.0.1 (SPSS Inc., Chicago, IL, USA). Association tests were performed by means of analyses of variance (ANOVA) with the polymorphisms as independent variables and NEO Neuroticism or its facet scales as dependent variables. The discriminant validity of possible results was assessed by means of an analysis of variance with the other four NEO domain scales as dependent variables, and convergent validity (ie stability of potential effects remained across measurement methods) was assessed by repeating the respective ANOVAs with TPQ Harm Avoidance as the dependent variable. Age and gender were included as covariates in the analyses to control for possible confounding effects of demographic variables. In all analyses, there was a significant covariate effect of gender, with women scoring higher on Neuroticism and on its facet scales (except for N5-Impulsivity), as well as on Harm Avoidance. Similarly, a significant covariate effect of age was observed in some of the analyses, with younger participants exhibiting higher Neuroticism scores. Uncorrected two-tailed $p$-values are reported throughout the manuscript, and where applicable, Bonferroni-corrected significance levels are given. Otherwise, the type I error rate is 0.05 .

\section{RESULTS}

First, we tested the hypothesis that Neuroticism is influenced by the BDNF Val66Met polymorphism using a univariate ANOVA with the BDNF Met/Met vs Val/Met vs $\mathrm{Val} / \mathrm{Val}$ genotype as independent variable and the Neuroticism domain score as dependent variable. There was no significant effect of Val66Met on Neuroticism scores $\left(\mathrm{F}_{2,267}=0.04, p=0.963\right)$. Similarly, when performing a multivariate ANOVA with the six Neuroticism facet scales as dependent variables, neither a multivariate effect (Wilks Lambda, $p>0.05$ ) nor the univariate effects of Val66Met on any of the facet scales were observed (all $p>0.05$ ). Raw means and standard errors of means of the Neuroticism domain and facet scale scores grouped by BDNF Val66Met genotype, as well as the number of individuals in each group are given in Table 1.

Next, we examined potential interactive effects of BDNF Val66Met, 5-HTTLPR, and the DAT VNTR on Neuroticism using a univariate ANOVA with dichotomized genotypes for Val66Met $(\mathrm{Met}+=\mathrm{Met} / \mathrm{Met}$ and $\mathrm{Val} / \mathrm{Met}$ vs Met $-=\mathrm{Val} /$ Val), 5-HTTLPR $(\mathrm{L}=1 / 1$ vs $\mathrm{S}=1 / \mathrm{s}$ and $\mathrm{s} / \mathrm{s})$, and DAT VNTR $(9+=9 / 9$ and $9 / 10$ vs $9-=10 / 10)$ as independent variables. Because of limitations in sample size, an unsaturated model was chosen, focusing on the three main effects and the three two-way interactions while neglecting the threeway interaction. Because six significance tests were performed (three main effects and three two-way interactions), the level of significance was Bonferroni-adjusted resulting in $\alpha^{\prime}=0.0083$. No main effects of the three polymorphisms and no significant interactions between Val66Met and 5-HTTLPR, and between 5-HTTLPR and DAT VNTR, respectively, were observed (all $p>0.05$ ). However, there was a Val66Met by DAT VNTR interaction effect on Neuroticism, significant at the Bonferroni-adjusted level $\left(\mathrm{F}_{1,262}=7.23, p=0.008, \eta^{2}=0.03\right.$; Figure 1$)$. A post hoc ANOVA performed separately for carriers and noncarriers of the DAT 9-repeat allele revealed that among individuals with at least one copy of the DAT 9-repeat allele, carriers of the BDNF Met allele had lower Neuroticism scores compared with noncarriers $\left(\mathrm{F}_{1,114}=4.28, \quad p=0.041\right.$; $\left.\eta^{2}=0.04\right)$. Among individuals lacking the DAT 9-repeat allele, there were no significant differences in Neuroticism scores between carriers and noncarriers of the BDNF Met allele $\left(\mathrm{F}_{1,150}=1.95, p=0.165\right)$.

A subsequent analysis with regard to the Neuroticism facets, therefore, focused only on the observed interaction between Val66Met (Met $+v s$ Met-) and DAT VNTR $(9+v s$ $9-)$ variants. Table 2 gives the respective raw means and

Table I Neuroticism Domain and Facet Scale Means and Standard Errors of Mean (SEM) by BDNF Met/Met vs Val/Met vs Val/Val Genotype

\begin{tabular}{|c|c|c|c|c|c|c|c|c|}
\hline BNDF & $n$ & $\mathbf{N}$ & NI & $\mathbf{N} 2$ & N3 & N4 & N5 & N6 \\
\hline Met/Met & 9 & $93.2(6.1)$ & I5.9(I.8) & I3.3 (I.3) & $14.7(1.7)$ & I6.7 (I.8) & $19.6(1.3)$ & I3.1 (1.6) \\
\hline Val/Met & 74 & $95.6(2.8)$ & $17.4(0.7)$ & I3.3 (0.6) & $15.2(0.7)$ & I $8.4(0.6)$ & | $8.2(0.6)$ & I3.| (0.6) \\
\hline Val/Val & 189 & $95.5(1.9)$ & I $7.2(0.5)$ & 14.3(0.4) & I $5.5(0.5)$ & $17.5(0.4)$ & $17.9(0.3)$ & |3.| (0.4) \\
\hline
\end{tabular}

$\mathrm{N}=$ Neuroticism domain scale score; NI-N6= Neuroticism facet scale scores; NI = Anxiety; N2=Angry Hostility; N3 = Depression; N4 = Self-consciousness; N5 = Impulsiveness; N6 = Vulnerability. 
standard errors of means of NEO-PI-R Neuroticism domain and facet scale scores. (Descriptive statistics for the BNDF Val66Met by DAT VNTR full $3 \times 3$ genotype grouping as well as for the dichotomized $2 \times 2$ and full $3 \times 3$ genotype groupings for BDNF by 5-HTTLPR, and for 5-HTTLPR by DAT VNTR, respectively, are available as Supplementary information at the Neuropsychopharmacology website, http://www.nature.com/npp.) The results of the ANOVA showed that the interaction effect of Val66Met and DAT VNTR on Neuroticism observed in the previous analysis was due to univariate interactive effects of the two polymorphisms on N1: Anxiety $\left(\mathrm{F}_{1,266}=4.63, p=0.032\right.$, $\left.\eta^{2}=0.02\right), \quad \mathrm{N} 3: \quad$ Depression $\quad\left(\mathrm{F}_{1,266}=9.14, \quad p=0.003\right.$, $\left.\eta^{2}=0.03\right)$, N4: Self-consciousness $\left(\mathrm{F}_{1,266}=3.94, p=0.048\right.$, $\left.\eta^{2}=0.02\right)$, and N6: Vulnerability $\left(\mathrm{F}_{1,266}=10.79, p=0.001\right.$, $\left.\eta^{2}=0.04\right)$. For N2: Angry Hostility, and for N5: Impulsive-

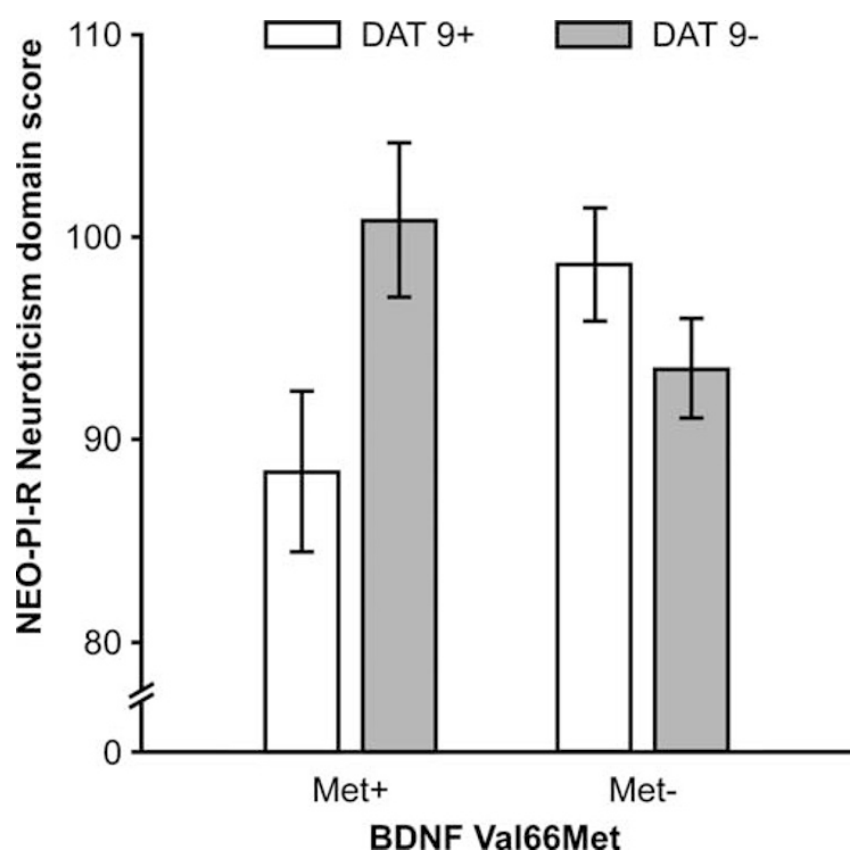

Figure I Interaction effect of DATI (presence vs absence of the 9repeat allele, 9+ vs 9-) and BDNF polymorphism (presence vs absence of the Met allele, Met + vs Met-) on NEO-PI-R Neuroticism scores $(p=0.008$, uncorrected); among carriers of the DATI 9-repeat allele, carriers of the BDNF Met allele exhibit lower Neuroticism scores compared with noncarriers ( $p=0.04 \mathrm{I}$, uncorrected); among individuals without the DATI 9-repeat allele, there are no significant differences in Neuroticism scores between the two BDNF genotypes $(p=0.165$, uncorrected; for details of the ANOVA, see text). ness, respectively, the interaction effects were not significant $(p>0.05)$. There were no main effects of BDNF Val66Met and DAT VNTR on Neuroticism facets (all $p>0.05$ ). As we performed 18 tests of significance (two main effects and one interaction for six dependent variables), the level of significance was Bonferroni-adjusted resulting in $\alpha^{\prime}=0.0028$. At this level, only the interaction effect on N6: Vulnerability remained significant, whereas the effect on N3: Depression was significant at the trend level.

An ANOVA utilizing the four other NEO domain scales (Extraversion, Openness, Agreeableness, and Conscientiousness) as dependent variables demonstrated discriminant validity of the results obtained in the previous analyses. No significant main effects of BDNF Val66Met $($ Met $+v s$ Met-) or DAT VNTR $(9+v s 9-)$, and no interactions emerged (all $p>0.05$, all $\eta^{2}<0.01$ ). Furthermore, an examination of convergent validity employing TPQ Harm Avoidance as dependent variable revealed a significant BDNF Val66Met by DAT VNTR interaction effect $\left(\mathrm{F}_{1,266}=6.87, p=0.009, \eta^{2}=0.03\right)$, whereas again, BDNF Val66Met or DAT VNTR main effects were not detected (all $p \geqslant 0.05$ ). In the presence of the DAT 9-repeat allele, carriers of the BDNF Met allele had significantly lower Harm Avoidance scores than noncarriers of the Met allele $\left(\mathrm{F}_{1,114}=6.57, p=0.012, \eta^{2}=0.06\right)$.

\section{DISCUSSION}

The results of the present study provide evidence for a DAT VNTR-dependent association between NEO-PI-R Neuroticism and the BDNF Val66Met polymorphism, further supporting the notion that allelic variation at the BDNF locus influences anxiety- and depression-related traits, and indicate that these traits are likely to result from an interaction of several or multiple genes. Among individuals with at least one copy of the DAT 9-repeat allele, carriers of the BDNF Met allele exhibit significantly lower Neuroticism scores than noncarriers. Convergent and discriminant validity of this result was verified by showing that this interaction is also observed for TPQ Harm Avoidance, a personality trait similar to Neuroticism, whereas there was no interaction between BDNF Val66Met and DAT VNTR on the other four NEO domain scales. In previous studies, Neuroticism has clearly been found to be associated with both PTSD (Bowman, 1999; Holeva and Tarrier, 2001) and depression (Enns and Cox, 1997).

Table 2 Neuroticism Domain and Facet Scale Means and Standard Errors of Mean (SEM) by BDNF Met+ (= Met/Met and Val/Met) vs Met $-(=\mathrm{Val} / \mathrm{Val})$ and DATI $9+(=9 / 9$ and $9 / 10)$ vs $9-(=10 / 10)$ Genotype

\begin{tabular}{lccccccccc}
\hline BNDF & DATI & N & N & NI & N2 & N3 & N4 & N5 & N6 \\
\hline Met+ & $9+$ & 33 & $89.8(3.6)$ & $15.9(0.9)$ & $13.0(0.7)$ & $13.5(1.0)$ & $17.5(0.8)$ & $18.2(0.7)$ & $11.7(0.8)$ \\
& $9-$ & 50 & $99.9(3.5)$ & $18.4(1.0)$ & $13.6(0.8)$ & $16.5(0.8)$ & $18.8(0.7)$ & $18.4(0.8)$ & $14.3(0.7)$ \\
Met- & $9+$ & 65 & $97.0(3.0)$ & $17.5(0.8)$ & $14.3(0.6)$ & $16.1(0.8)$ & $17.9(0.6)$ & $17.4(0.5)$ & $13.8(0.6)$ \\
& $9-$ & 123 & $94.4(2.5)$ & $17.0(0.7)$ & $14.3(0.5)$ & $15.0(0.6)$ & $17.2(0.5)$ & $18.3(0.4)$ & $12.6(0.5)$ \\
\hline
\end{tabular}

$\mathrm{N}=$ Neuroticism domain scale score; NI-N6= Neuroticism facet scale scores; NI = Anxiety; N2 = Angry Hostility; N3 = Depression; N4 = Self-consciousness;

N5 = Impulsiveness; N6 = Vulnerability. 
Although our findings confirm a role of BDNF Val66Met polymorphism in anxiety- and depression-related traits, we did not succeed in replicating the previously reported direct association between the BDNF Met variant and low Neuroticism. This failure may, in part, be due to the smaller sample size of the present study relative to the initial report by Sen et al (2003). The present study has a $65 \%$ power to detect an effect that accounts for about $2 \%$ of the phenotypic variance as estimated from the previously reported data. A problem of statistical power may also be reflected by the lack of evidence for an association between 5 -HTTLPR and Neuroticism in our sample. Previous reports have indicated that sample size is critical for the detection of the 5-HTTLPR-Neuroticism association (Lesch et al, 1996; Greenberg et al, 2000). In the present study on the level of the Neuroticism facets, the BDNF-DAT interaction was significant at the conventional 5\% level for the NEO subscales N1: Anxiety, N3: Depression, N4: Self-consciousness, and N6: Vulnerability. It is noteworthy that these facets are exactly the same as those associated with BDNF in the study by Sen et al (2003). Although after Bonferroni correction, only the effects on N6: Vulnerability and (at the trend level) N3: Depression were still significant, it has to be noted that Bonferroni correction might be too conservative in analyses with highly inter-related dependent variables.

Beyond Sen's report and our results, there is further evidence of BDNF playing a crucial role in the pathophysiology of anxiety and depression spectrum disorders. Four family-based studies revealed a preferential transmission of the BDNF Val allele to bipolar individuals (Neves-Pereira et al, 2002; Sklar et al, 2002; Geller et al, 2004; Lohoff et al, 2005). Recently, Strauss et al $(2004,2005)$ discovered in two independent samples that the $\mathrm{Val}$ allele is associated with childhood-onset mood disorder. Concordantly, carriers of the Val/Val genotype showed higher levels in anxietyrelated traits and a trend to increased Neuroticism scores (Lang et al, 2005). All these investigations found the Val allele connected to a higher degree with anxiety and depressive symptoms. One might, therefore, expect the Val allele to be associated with characteristic memory disturbance and hippocampal dysfunction seen in stressrelated disorders. However, Egan et al (2003) observed poorer episodic memory, abnormal functional magnetic resonance imaging (fMRI)-assayed hippocampal activation, and lower hippocampal $\mathrm{N}$-acetyl aspartate assayed with MRI spectroscopy in human participants carrying the BDNF Met not the Val allele. Hariri et al (2003) also revealed a diminished hippocampal engagement and memory impairment associated with the Met allele. Furthermore, Met allele carriers had relative decreases in hippocampal and prefrontal cortical volume, the two brain regions that show especially abundant expression of BDNF (Pezawas et al, 2004; Szeszko et al, 2005). As a possible explanation at the molecular level, neuronal cultures transfected with the Met allele present abnormal intracellular trafficking and depolarization-induced secretion of BDNF (Egan et al, 2003; Chen et al, 2004). Unfortunately, these authors did not include personality measures in their study; so currently, this apparent contradiction cannot be resolved and requires further investigation.

It should be mentioned that several authors were unable to affirm that BDNF Val66Met modifies personality dimen- sions or disposes to mood disorders at all (Hong et al, 2003; Kunugi et al, 2004; Skibinska et al, 2004; Tsai et al, 2004). Using the Eysenck Personality Questionnaire, Willis-Owen et al (2005) failed to report an association of BDNF Val66Met with Neuroticism, which opposes results found with the TPQ. Contradicting our results, Jiang et al (2005) found the BDNF Met allele connected with elevated Harm Avoidance scores. Their varying study design and the use of different diagnostic inventories might explain this divergent outcome. Moreover, population stratification as an artifact could have influenced our positive interaction as BDNF gene variants show heterogeneity across populations.

Nevertheless, further evidence for an involvement of the BDNF Val66Met polymorphism in the modulation of anxiety-related behavior comes from a recent publication (Chen et al, 2006). In their study, a variant BDNF mouse (BDNF Met/Met) showed a normal BDNF Met expression in the brain, but a defective BDNF secretion from neurons. Furthermore, the Met allele was associated with increased anxiety-related behaviors of these mice under stressful conditions, an effect that could not be normalized by antidepressant medication with fluoxetine.

In our study, BDNF Val66Met in interaction with a DAT VNTR influences the personality dimensions Neuroticism and Harm Avoidance. The dopamine transporter mediates the uptake of dopamine into neurons, and is a major target for various stimulants. The 40-bp VNTR is located in the $3^{\prime}$-untranslated region adjacent to the polyadenylation site of the human DAT gene. It is likely to give rise to the formation of DNA secondary structure that has the potential to regulate DAT gene transcription, mRNA concentration, protein availability, and, ultimately, transporter function. Evidence that the DAT VNTR contributes to variability in DAT gene expression is ample albeit inconclusive. The 9-repeat allele of the DAT VNTR has been reported to be associated with either lower (Fuke et al, 2001; Mill et al, 2002) or higher levels of DAT expression (Michelhaugh et al, 2001; Miller and Madras, 2002). Furthermore, neuroimaging studies in humans have found the DAT 9-repeat allele associated with either reduced (Heinz et al, 2000) or elevated striatal dopamine transporter binding (Jacobsen et al, 2000; van Dyck et al, 2005), whereas other studies observed no effect at all (Martinez et al, 2001; Lynch et al, 2003). These apparent discrepancies may arise from a number of reasons, including the existence of allele diversity independent of the length of the DAT VNTR, cell type-specific or developmentally differentiated regulation of the DAT gene transcript levels and stability, as well as genegene and gene-environment effects impacting on the DAT gene expression.

Association studies provide considerable evidence that the DAT VNTR 10-repeat allele is associated with attentiondeficit hyperactivity disorder (ADHD) (Cook et al, 1995; Gill et al, 1997; Waldman et al, 1998; Daly et al, 1999; Barr et al, 2001; Curran et al, 2001; Chen et al, 2003), although several nonreplications have been reported (Palmer et al, 1999; Holmes et al, 2000; Todd et al, 2001; Langley et al, 2005). In vivo studies using single photon emission computed tomography (SPECT) show an increased density of striatal DAT in ADHD subjects compared with controls (Dougherty et al, 1999; Dresel et al, 2000; Krause et al, 2000, 2003). Cheon et al (2005) found a higher DAT density in the 
basal ganglia of ADHD children with VNTR 10/10 genotype, suggesting that there might be an association between the VNTR genotype and DAT density.

Furthermore, there is strong evidence for a role of DAT VNTR in alcohol-withdrawal symptoms (Sander et al, 1997; Schmidt et al, 1998; Gorwood et al, 2003). Its relevance to smoking behavior (Lerman et al, 1999; Sabol et al, 1999; Jorm et al, 2000; Vandenbergh et al, 2002; Erblich et al, $2005)$ is still tentative. With regard to the pathophysiology of stress-related disorders, the role of DAT VNTR in bipolar disorder is inconclusive as well (Souery et al, 1996; GomezCasero et al, 1996; Waldman et al, 1997; Georgieva et al, 2002). Neuroimaging studies observed a reduced striatal dopamine transporter binding in patients suffering from major depression (Meyer et al, 2001) or seasonal affective disorder (Neumeister et al, 2001), whereas another study reported elevated striatal dopamine transporter binding in depressed patients (Laasonen-Balk et al, 1999). In the light of the likely yet unclear influences of genetic variation in DAT on gene expression and transporter function, these divergent findings may not be surprising. It remains to be seen if the recent finding of an excess of the DAT 9-repeat allele in patients with PTSD (Segman et al, 2002) can be replicated more consistently.

The question arises how the interaction of BDNF and DAT on Neuroticism and Harm Avoidance may be explained on the basis of present knowledge. Indeed, there is strong evidence for various interactions of BDNF and the central dopaminergic system. Dopaminergic neurons in rat ventral midbrain were discovered to express BDNF-mRNA (Seroogy et al, 1994) and neurotrophin receptor TrkB and TrkC-mRNA (Numan and Seroogy, 1999). Several authors were able to detect BDNF in combination with dopamine to induce the dopaminergic phenotype in fetal rat and human cerebral cortex cultures (Hyman et al, 1994; Zhou et al, 1994, 1996, 1998; Theofilopoulos et al, 2001; Riaz et al, 2002, 2004). Stimulation with dopamine results in increased BDNF-mRNA and -protein in neuronal cultures (Küppers and Beyer, 2001). A BDNF infusion into the substantia nigra increases dopamine turnover in the striatum (MartinIverson et al, 1994), whereas a loss of BDNF expression leads both to downregulation of the dopaminergic phenotype and to dopaminergic neuronal death (Porritt et al, 2005). Recently, Berton et al (2006) reported that BDNF plays an essential role in the mesolimbic dopamine pathway in social defeat stress. Developing a murine model relevant to human psychiatric conditions such as depression, social phobia, and PTSD, mice showed a long-lasting social withdrawal after the experience of repeated aggression. Berton et al revealed that BDNF is required for the development of experience-dependent social aversion using a mesolimbic dopamine pathway-specific knockdown of BDNF. Local deletion of this neurotrophin in the ventral tegmental area-as well as chronic treatment with antidepressants-reverses the effect of social defeat. This profile is opposite to the antidepressant-like activity of BDNF reported in the above-mentioned hippocampal studies. In conclusion, there is a great amount of evidence that there is a close connection of central BDNF and the dopaminergic system.

Several studies revealed gene-gene interaction in the modification of personality dimensions. Noble et al (1998) found an association of the D2 and D4 receptors (DRD2, DRD4) and Novelty Seeking. The combined DRD2 and DRD4 polymorphisms contributed more markedly to this personality trait than when these two polymorphisms were considered individually. Furthermore, Benjamin et al (2000) described a replicable interaction of 5-HTT, DRD4, and COMT that influences Novelty Seeking scores (Strobel et al, 2003). It is likely that an interplay of several or multiple gene variants in particular determines a characteristic personality dimension.

In conclusion, our study reveals a DAT VNTR-dependent association between NEO-PI-R Neuroticism and the BDNF Val66Met polymorphism, but fails to replicate the previously reported direct association between the BDNF Met variant and low Neuroticism. Our results further support the notion that allelic variation at the BDNF locus - in interaction with several genes-influences anxiety- and depression-related personality traits and modulates liability to stress-related disorders.

\section{ACKNOWLEDGEMENTS}

We thank J Müller for helpful comments during the preparation of the article. The study was supported by a grant from the Deutsche Forschungsgemeinschaft (SFB 581).

\section{REFERENCES}

Barr CL, Xu C, Kroft J, Feng Y, Wigg K, Zai G et al (2001). Haplotype study of three polymorphisms at the dopamine transporter locus confirm linkage to attention-deficit/hyperactivity disorder. Biol Psychiatry 49: 333-339.

Benjamin J, Osher Y, Kotler M, Gritsenko I, Nemanov L, Belmaker RH et al (2000). Association between tridimensional personality questionnaire (TPQ) traits and three functional polymorphisms: dopamine receptor D4 (DRD4), serotonin transporter promoter region (5-HTTLPR) and catechol O-methyltransferase (COMT). Mol Psychiatry 5: 96-100.

Berton O, McClung CA, DiLeone RJ, Krishnan V, Renthal W, Russo SJ et al (2006). Essential role of BDNF in the mesolimbic dopamine pathway in social defeat stress. Science 311: 864-868.

Bonhoeffer T (1996). Neurotrophins and activity-dependent development of the neocortex. Curr Opin Neurobiol 6: 119-126.

Bowman ML (1999). Individual differences in posttraumatic distress: problems with the DSM-IV model. Can J Psychiatry 44: 21-33.

Canals JM, Checa N, Marco S, Åkerud P, Michels A, Pérez-Navarro E et al (2001). Expression of brain-derived neurotrophic factor in cortical neurons is regulated by striatal target area. J Neurosci 21: $117-124$.

Carter AR, Chen C, Schwartz PM, Segal RA (2002). Brain-derived neurotrophic factor modulates cerebellar plasticity and synaptic ultrastructure. J Neurosci 22: 1316-1327.

Chen CK, Chen SL, Mill J, Huang YS, Lin SK, Curran S (2003). The dopamine transporter gene is associated with attention deficit hyperactivity disorder in a Taiwanese sample. Mol Psychiatry 8: 393-396.

Chen ZY, Jing D, Bath KG, Ieraci A, Khan T, Siao CJ et al (2006). Genetic variant BDNF (Val66Met) polymorphism alters anxietyrelated behavior. Science 314: 140-143.

Chen ZY, Patel PD, Sant G, Meng CX, Teng KK, Hempstead BL et al (2004). Variant brain-derived neurotrophic factor (BDNF) (met66) alters the intracellular trafficking and activity-depen- 
dent secretion of wild-type BDNF in neurosecretory cells and cortical neurons. J Neurosci 24: 4401-4411.

Cheon KA, Ryu YH, Kim JW, Cho DY (2005). The homozygosity for 10-repeat allele at dopamine transporter gene and dopamine transporter density in Korean children with attention deficit hyperactivity disorder: relating to treatment response to methylphenidate. Eur Neuropsychopharmacol 15: 95-101.

Cloninger CR (1987). A systematic method for clinical description and classification of personality variants. A proposal. Arch Gen Psychiatry 44: 573-588.

Cloninger CR, Svrakic DM, Przybeck TR (1993). A psychobiological model of temperament and character. Arch Gen Psychiatry 30: 975-990.

Cook Jr EH, Stein MS, Krasowski MD, Cox NJ, Olkon DM, Kieffer JE et al (1995). Association of attention-deficit disorder and the dopamine transporter gene. Am J Hum Genet 56: 993-996.

Costa Jr PT, McCrae RR (1992). Revised NEO Personality Inventory (NEO PI-R) and NEO Five-Factor Inventory (NEO-FFI). Professional Manual. Psychological Assessment Resources: Odessa, FL.

Curran S, Mill J, Tahir E, Kent L, Richards S, Gould A et al (2001). Association study of a dopamine transporter polymorphism and attention deficit hyperactivity disorder in UK and Turkish samples. Mol Psychiatry 6: 425-428.

D'Sa C, Duman RS (2002). Antidepressants and neuroplasticity. Bipolar Disord 4: 183-194.

Daly G, Hawi Z, Fitzgerald M, Gill M (1999). Mapping susceptibility loci in attention deficit hyperactivity disorder: preferential transmission of parental alleles at DAT1, DBH and DRD5 to affected children. Mol Psychiatry 4: 192-196.

Dougherty DD, Bonab AA, Spencer TJ, Rauch SL, Madras BK, Fischman AJ (1999). Dopamine transporter density in patients with attention deficit hyperactivity disorder. Lancet 354: 2132-2133.

Dresel S, Krause J, Krause KH, LaFougere C, Brinkbaumer K, Kung HF et al (2000). Attention deficit hyperactivity disorder: binding of [99mTc]TRODAT-1 to the dopamine transporter before and after methylphenidate treatment. Eur J Nucl Med 27: 1518-1524.

Duman RS, Heninger GR, Nestler EJ (1997). A molecular and cellular theory of depression. Arch Gen Psychiatry 54: 597-606.

Duman RS, Malberg J, Nakagawa S (2001). Regulation of adult neurogenesis by psychotropic drugs and stress. J Pharmacol Exp Ther 299: 401-407.

Egan MF, Kojima M, Callicott JH, Goldberg TE, Kolachana BS, Bertolino A et al (2003). The BDNF val66met polymorphism affects activity-dependent secretion of BDNF and human memory and hippocampal function. Cell 112: 257-269.

Enns MW, Cox BJ (1997). Personality dimensions and depression: review and commentary. Can J Psychiatry 42: 274-284.

Erblich J, Lerman C, Self DW, Diaz GA, Bovbjerg DH (2005). Effects of dopamine D2 receptor (DRD2) and transporter (SLC6A3) polymorphisms on smoking cue-induced cigarette craving among African-American smokers. Mol Psychiatry 10: 407-414.

Eysenck HJ, Eysenck SBG (1985). Personality and Individual Differences: A Natural Science Approach. Plenum: New York.

Fuke S, Suo S, Takahashi N, Koike H, Sasagawa N, Ishiura S (2001). The VNTR polymorphism of the human dopamine transporter (DAT1) gene affects gene expression. Pharmacogenomics $J$ 1: 152-156.

Garcia R (2002). Stress, synaptic plasticity, and psychopathology. Rev Neurosci 13: 195-208.

Geller B, Badner JA, Tillman R, Christian SL, Bolhofner K, Cook Jr EH (2004). Linkage disequilibrium of the brain-derived neurotrophic factor val66met polymorphism in children with a prepubertal and early adolescent bipolar disorder phenotype. Am J Psychiatry 161: 1698-1700.

Georgieva L, Dimitrova A, Nikolov I, Koleva S, Tsvetkova R, Owen MJ et al (2002). Dopamine transporter gene (DAT1) VNTR polymorphism in major psychiatric disorders: family-based association study in the Bulgarian population. Acta Psychiatr Scand 105: 396-399.

Gill M, Daly G, Heron S, Hawi Z, Fitzgerald M (1997). Confirmation of association between attention deficit hyperactivity disorder and a dopamine transporter polymorphism. Mol Psychiatry 2: 311-313.

Goggi J, Pullar IA, Carney SL, Bradford HF (2002). Modulation of neurotransmitter release induced by brain-derived neurotrophic factor in rat brain striatal slices in vitro. Brain Res 941: 34-42.

Gomez-Casero E, Perez de Castro I, Saiz-Ruiz J, Llinares C, Fernandez-Piqueras J (1996). No association between particular DRD3 and DAT gene polymorphisms and manic-depressive illness in a Spanish sample. Psychiatr Genet 6: 209-212.

Gorwood P, Limosin F, Batel P, Hamon M, Ades J, Boni C (2003). The A9 allele of the dopamine transporter gene is associated with delirium tremens and alcohol-withdrawal seizure. Biol Psychiatry 53: 85-92.

Greenberg BD, Li Q, Lucas FR, Hu S, Sirota LA, Benjamin J et al (2000). Association between the serotonin transporter promoter polymorphism and personality traits in a primarily female population sample. Am J Med Genet 96: 202-216.

Hariri AR, Goldberg TE, Mattay VS, Kolachana BS, Callicott JH, Egan MF et al (2003). Brain-derived neurotrophic factor val66met polymorphism affects human memory-related hippocampal activity and predicts memory performance. $J$ Neurosci 23: 6690-6694.

Heinz A, Goldman D, Jones DW, Palmour R, Hommer D, Gorey JG et al (2000). Genotype influences in vivo dopamine transporter availability in human striatum. Neuropsychopharmacology 22: 133-139.

Holeva V, Tarrier N (2001). Personality and peritraumatic dissociation in the prediction of PTSD in victims of road traffic accidents. J Psychosom Res 51: 687-692.

Holmes J, Payton A, Barrett JH, Hever T, Fitzpatrick H, Trumper $\mathrm{AL}$ et al (2000). A family-based and case-control association study of the dopamine D4 receptor gene and dopamine transporter gene in attention deficit hyperactivity disorder Mol Psychiatry 5: 523-530.

Hong CJ, Huo SJ, Yen FC, Tung CL, Pan GM, Tsai SJ (2003). Association study of a brain-derived neurotrophic-factor genetic polymorphism and mood disorders, age of onset and suicidal behavior. Neuropsychobiology 48: 186-189.

Hull AM (2002). Neuroimaging findings in post-traumatic stress disorder: systematic review. Br J Psychiatry 181: 102-110.

Hyman C, Juhasz M, Jackson C, Wright P, Ip NY, Lindsay RM (1994). Overlapping and distinct actions of the neurotrophins BDNF, NT-3, and NT-4/5 on cultured dopaminergic and GABAergic neurons of the ventral mesencephalon. J Neurosci 14: 335-347.

Jacobsen LK, Staley JK, Zoghbi SS, Seibyl JP, Kosten TR, Innis RB et al (2000). Prediction of dopamine transporter binding availability by genotype: a preliminary report. Am J Psychiatry 157: 1700-1703.

Jiang X, Xu K, Hoberman J, Tian F, Marko AJ, Waheed JF et al (2005). BDNF variation and mood disorders: a novel functional promoter polymorphism and val66met are associated with anxiety but have opposing effects. Neuropsychopharmacology 30: $1353-1361$.

Jorm AF, Henderson AS, Jacomb PA, Christensen H, Korten AE, Rodgers B et al (2000). Association of smoking and personality with a polymorphism of the dopamine transporter gene: results from a community survey. Am J Med Genet 96: 331-334.

Kendler KS, Neale MC, Kessler RC, Heath AC, Eaves LJ (1993). A longitudinal twin study of personality and major depression in women. Arch Gen Psychiatry 50: 853-862.

Kernie SG, Liebl DJ, Parada LF (2000). BDNF regulates eating behavior and locomotor activity in mice. EMBO J 19: 1290-1300.

Krause KH, Dresel SH, Krause J, Kung HF, Tatsch K (2000). Increased striatal dopamine transporter in adult patients with 
attention deficit hyperactivity disorder: effects of methylphenidate as measured by single photon emission computed tomography. Neurosci Lett 285: 107-110.

Krause KH, Dresel SH, Krause J, la Fougere C, Ackenheil M (2003). The dopamine transporter and neuroimaging in attention deficit hyperactivity disorder. Neurosci Biobehav Rev 27: 605-613.

Kunugi H, Iijima Y, Tatsumi M, Yoshida M, Hashimoto R, Kato T et al (2004). No association between the val66met polymorphism of the brain-derived neurotrophic factor gene and bipolar disorder in a Japanese population: a multicenter study. Biol Psychiatry 56: 376-378.

Küppers E, Beyer C (2001). Dopamine regulates brain-derived neurotrophic factor (BDNF) expression in cultured embryonic mouse striatal cells. NeuroReport 12: 1175-1179.

Laasonen-Balk T, Kuikka J, Viinamaki H, Husso-Saastamoinen M, Lehtonen J, Tiihonen J (1999). Striatal dopamine transporter density in major depression. Psychopharmacology (Berl) 144: 282-285.

Lang UE, Hellweg R, Kalus P, Bajbouj M, Lenzen KP, Sander T et al (2005). Association of a functional BDNF polymorphism and anxiety-related personality traits. Psychopharmacology (Berl) 180: 95-99.

Langley K, Turic D, Peirce TR, Mills S, Van Den Bree MB, Owen MJ et al (2005). No support for association between the dopamine transporter (DAT1) gene and ADHD. Am J Med Genet B Neuropsychiatr Genet 139: 7-10.

Lerman C, Caporaso NE, Audrain J, Main D, Bowman ED, Lockshin B et al (1999). Evidence suggesting the role of specific genetic factors in cigarette smoking disorder. Health Psychol 18: $14-20$.

Lesch KP (2001). Serotonin transporter: from genomics and knockouts to behavioral traits and psychiatric disorders. In: Briley M, Sulser F (eds). Molecular Genetics of Mental Disorders. Martin Dunitz Publishers: London. pp 221-267.

Lesch KP, Bengel D, Heils A, Sabol SZ, Greenberg BD, Petri S et al (1996). Association of anxiety-related traits with a polymorphism in the serotonin transporter gene regulatory region. Science 274: 1527-1531.

Lohoff FW, Sander T, Ferraro TN, Dahl JP, Gallinat J, Berrettini WH (2005). Confirmation of association between the val66met polymorphism in the brain-derived neurotrophic factor (BDNF) gene and bipolar I disorder. Am J Med Genet B Neuropsychiatr Genet 139: 51-53.

Lu B, Chow A (1999). Neurotrophins and hippocampal synaptic transmission and plasticity. J Neurosci Res 58: 76-87.

Lynch DR, Mozley PD, Sokol S, Maas NM, Balcer LJ, Siderowf AD (2003). Lack of effect of polymorphisms in dopamine metabolism related genes on imaging of TRODAT-1 in striatum of asymptomatic volunteers and patients with Parkinson's disease. Mov Disord 18: 804-812.

Martinez D, Gelernter J, Abi-Dargham A, van Dyck CH, Kegeles L, Innis RB et al (2001). The variable number of tandem repeats polymorphism of the dopamine transporter gene is not associated with significant change in dopamine transporter phenotype in humans. Neuropsychopharmacology 24: 553-560.

Martin-Iverson MT, Todd KG, Altar CA (1994). Brain-derived neurotrophic factor and neurotrophin-3 activate striatal dopamine and serotonin metabolism and related behaviors: interactions with amphetamine. J Neurosci 14: 1262-1270.

McAllister AK, Katz LC, Lo DC (1999). Neurotrophins and synaptic plasticity. Annu Rev Neurosci 22: 295-318.

McEwen BS, Magarinos AM (2001). Stress and hippocampal plasticity: implications for the pathophysiology of affective disorders. Hum Psychopharmacol 16: 7-19.

Meltzer HY (1990). Role of serotonin in depression. Ann NY Acad Sci 600: 486-499.

Meyer JH, Kruger S, Wilson AA, Christensen BK, Goulding VS, Schaffer A et al (2001). Lower dopamine transporter binding potential in striatum during depression. NeuroReport 12: 4121-4125.

Michelhaugh SK, Fiskerstrand C, Lovejoy E, Bannon MJ, Quinn JP (2001). The dopamine transporter gene (SLC6A3) variable number of tandem repeats domain enhances transcription in dopamine neurons. J Neurochem 79: 1033-1038.

Mill J, Asherson P, Browes C, D'Souza U, Craig I (2002). Expression of the dopamine transporter gene is regulated by the $3^{\prime}$ UTR VNTR: evidence from brain and lymphocytes using quantitative RT-PCR. Am J Med Genet 114: 975-979.

Miller GM, Madras BK (2002). Polymorphisms in the $3^{\prime}$ untranslated region of human and monkey dopamine transporter genes affect reporter gene expression. Mol Psychiatry 7: 44-55.

Mössner R, Daniel S, Albert D, Heils A, Okladnova O, Schmitt A et al (2000). Serotonin transporter function is modulated by brain-derived neurotrophic factor (BDNF) but not nerve growth factor (NGF). Neurochem Int 36: 197-202.

Mössner R, Walitza S, Lesch KP, Geller F, Barth N, Remschmidt H et al (2005). Brain-derived neurotrophic factor V66M polymorphism in childhood-onset obsessive-compulsive disorder. Int J Neuropsychopharmacol 8: 133-136.

Neumeister A, Willeit M, Praschak-Rieder N, Asenbaum S, Stastny J, Hilger E et al (2001). Dopamine transporter availability in symptomatic depressed patients with seasonal affective disorder and healthy controls. Psychol Med 31: 1467-1473.

Neves-Pereira M, Mundo E, Muglia P, King N, Macciardi F, Kennedy JL (2002). The brain-derived neurotrophic factor gene confers susceptibility to bipolar disorder: evidence from a family-based association study. Am J Hum Genet 71: 651-655.

Noble EP, Ozkaragoz TZ, Ritchie TL, Zhang X, Belin TR, Sparkes RS (1998). D2 and D4 dopamine receptor polymorphisms and personality. Am J Med Genet 81: 257-267.

Numan S, Seroogy KB (1999). Expression of trkB and trkC mRNAs by adult midbrain dopamine neurons: a double-label in situ hybridization study. J Comp Neurol 403: 295-308.

Ostendorf F, Angleitner A (2003). NEO-Persönlichkeitsinventar (revidierte Form, NEO-PI-R) nach Costa und McCrae. Hogrefe: Göttingen.

Palmer CG, Bailey JN, Ramsey C, Cantwell D, Sinsheimer JS, Del'Homme M et al (1999). No evidence of linkage or linkage disequilibrium between DAT1 and attention deficit hyperactivity disorder in a large sample. Psychiatr Genet 9: 157-160.

Pezawas L, Verchinski BA, Mattay VS, Callicott JH, Kolachana BS, Straub RE et al (2004). The brain-derived neurotrophic factor val66met polymorphism and variation in human cortical morphology. J Neurosci 24: 10099-10102.

Poo MM (2001). Neurotrophins as synaptic modulators. Nat Rev Neurosci 2: 24-32.

Porritt MJ, Batchelor PE, Howells DW (2005). Inhibiting BDNF expression by antisense oligonucleotide infusion causes loss of nigral dopaminergic neurons. Exp Neurol 192: 226-234.

Rasmusson AM, Shi L, Duman R (2002). Downregulation of BDNF mRNA in the hippocampal dentate gyrus after re-exposure to cues previously associated with footshock. Neuropsychopharmacology 27: 133-142.

Riaz SS, Jauniaux E, Stern GM, Bradford HF (2002). The controlled conversion of human neural progenitor cells derived from foetal ventral mesencephalon into dopaminergic neurons in vitro. Brain Res Dev Brain Res 136: 27-34.

Riaz SS, Theofilopoulos S, Jauniaux E, Stern GM, Bradford HF (2004). The differentiation potential of human foetal neuronal progenitor cells in vitro. Brain Res Dev Brain Res 153: 39-51.

Sabol SZ, Nelson ML, Fisher C, Gunzerath L, Brody CL, Hu S et al (1999). A genetic association for cigarette smoking behavior. Health Psychol 18: 7-13.

Sander T, Harms H, Podschus J, Finckh U, Nickel B, Rolfs A et al (1997). Allelic association of a dopamine transporter gene 
polymorphism in alcohol dependence with withdrawal seizures or delirium. Biol Psychiatry 41: 299-304.

Schmidt LG, Harms H, Kuhn S, Rommelspacher H, Sander T (1998). Modification of alcohol withdrawal by the A9 allele of the dopamine transporter gene. Am J Psychiatry 155: 474-478.

Segman RH, Cooper-Kazaz R, Macciardi F, Goltser T, Halfon Y, Dobroborski T et al (2002). Association between the dopamine transporter gene and posttraumatic stress disorder. Mol Psychiatry 7: 903-907.

Sen S, Nesse RM, Stoltenberg SF, Li S, Gleiberman L, Chakravarti A et al (2003). A BDNF coding variant is associated with the NEO personality inventory domain neuroticism, a risk factor for depression. Neuropsychopharmacology 28: 397-401.

Seroogy KB, Lundgren KH, Tran TM, Guthrie KM, Isackson PJ, Gall CM (1994). Dopaminergic neurons in rat ventral midbrain express brain-derived neurotrophic factor and neurotrophin-3 mRNAs. J Comp Neurol 342: 321-334.

Skibinska M, Hauser J, Czerski PM, Leszczynska-Rodziewicz A, Kosmowska M, Kapelski P et al (2004). Association analysis of brain-derived neurotrophic factor (BDNF) gene val66met polymorphism in schizophrenia and bipolar affective disorder. World J Biol Psychiatry 5: 215-220.

Sklar P, Gabriel SB, McInnis MG, Bennett P, Lim YM, Tsan G et al (2002). Family-based association study of 76 candidate genes in bipolar disorder: BDNF is a potential risk locus. Mol Psychiatry 7: 579-593.

Souery D, Lipp O, Mahieu B, Mendelbaum K, De Martelaer V, Van Broeckhoven C et al (1996). Association study of bipolar disorder with candidate genes involved in catecholamine neurotransmission: DRD2, DRD3, DAT1, and TH genes. Am J Med Genet 67: 551-555.

Strauss J, Barr CL, George CJ, Devlin B, Vetro A, Kiss E et al (2005). Brain-derived neurotrophic factor variants are associated with childhood-onset mood disorder: confirmation in a Hungarian sample. Mol Psychiatry 10: 861-867.

Strauss J, Barr CL, George CJ, King N, Shaikh S, Devlin B et al (2004). Association study of brain-derived neurotrophic factor in adults with a history of childhood onset mood disorder. Am J Med Genet B Neuropsychiatr Genet 131: 16-19.

Strobel A, Lesch KP, Jatzke S, Paetzold F, Brocke B (2003). Further evidence for a modulation of novelty seeking by DRD4 exon III, 5-HTTLPR, and COMT val/met variants. Mol Psychiatry 8: 371-372.

Szeszko PR, Lipsky R, Mentschel C, Robinson D, Gunduz-Bruce H, Sevy S et al (2005). Brain-derived neurotrophic factor val66met polymorphism and volume of the hippocampal formation. Mol Psychiatry 10: 631-636.

Theofilopoulos S, Goggi J, Riaz SS, Jauniaux E, Stern GM, Bradford HF (2001). Parallel induction of the formation of dopamine and its metabolites with induction of tyrosine hydroxylase expression in foetal rat and human cerebral cortical cells by brainderived neurotrophic factor and glial-cell derived neurotrophic factor. Brain Res Dev Brain Res 127: 111-122.

Todd RD, Jong YJ, Lobos EA, Reich W, Heath AC, Neuman RJ (2001). No association of the dopamine transporter gene $3^{\prime}$ VNTR polymorphism with ADHD subtypes in a population sample of twins. Am J Med Genet 105: 745-748.

Tsai SJ, Hong CJ, Yu YW, Chen TJ (2004). Association study of a brain-derived neurotrophic factor (BDNF) val66met polymorphism and personality trait and intelligence in healthy young females. Neuropsychobiology 49: 13-16.

Tyler WJ, Alonso M, Bramham CR, Pozzo-Miller LD (2002). From acquisition to consolidation: on the role of brain-derived neurotrophic factor signaling in hippocampal-dependent learning. Learn Mem 9: 224-237.

van Dyck CH, Malison RT, Jacobsen LK, Seibyl JP, Staley JK, Laruelle $\mathrm{M}$ et al (2005). Increased dopamine transporter availability associated with the 9-repeat allele of the SLC6A3 gene. J Nucl Med 46: 745-751.

Vandenbergh DJ, Bennett CJ, Grant MD, Strasser AA, O'Connor R, Stauffer RL et al (2002). Smoking status and the human dopamine transporter variable number of tandem repeats (VNTR) polymorphism: failure to replicate and finding that never-smokers may be different. Nicotine Tob Res 4: 333-340.

Vermetten E, Bremner JD (2002). Circuits and systems in stress. I. Preclinical studies. Depress Anxiety 15: 126-147.

Vitalis T, Cases O, Gillies K, Hanoun N, Hamon M, Seif I et al (2002). Interactions between TrkB signaling and serotonin excess in the developing murine somatosensory cortex: a role in tangential and radial organization of thalamocortical axons. J Neurosci 22: 4987-5000.

Vollmayr B, Keck S, Henn FA, Schloss P (2000). Acute stress decreases serotonin transporter mRNA in the raphe pontis but not in other raphe nuclei of the rat. Neurosci Lett 290: 109-112.

Waldman ID, Robinson BF, Feigon SA (1997). Linkage disequilibrium between the dopamine transporter gene (DAT1) and bipolar disorder: extending the transmission disequilibrium test (TDT) to examine genetic heterogeneity. Genet Epidemiol 14: 699-704.

Waldman ID, Rowe DC, Abramowitz A, Kozel ST, Mohr JH, Sherman SL et al (1998). Association and linkage of the dopamine transporter gene and attention-deficit hyperactivity disorder in children: heterogeneity owing to diagnostic subtype and severity. Am J Hum Genet 63: 1767-1776.

Watson D, Tellegen A (1985). Toward a consensual structure of mood. Psychol Bull 98: 219-235.

Weyers P, Krebs H, Janke W (1995). Reliability and construct validity of a German version of Cloninger's tridimensional personality questionnaire. Pers Ind Diff 19: 853-861.

Willis-Owen SA, Fullerton J, Surtees PG, Wainwright NW, Miller S, Flint J (2005). The val66met coding variant of the brain-derived neurotrophic factor (BDNF) gene does not contribute toward variation in the personality trait neuroticism. Biol Psychiatry 58: 738-742.

Willner P, Muscat R, Papp M, Sampson D (1991). Dopamine, depression and anti-depressant drugs. In: Willner P, ScheelKrüger J (eds). The Mesolimbic Dopamine System: from Motivation to Action. John Wiley \& Sons: Chichester. pp 387-410.

Xu B, Gottschalk W, Chow A, Wilson RI, Schnell E, Zang K et al (2000). The role of brain-derived neurotrophic factor receptors in the mature hippocampus: modulation of long-term potentiation through a presynaptic mechanism involving TrkB. J Neurosci 20: 6888-6897.

Yamada K, Mizuno M, Nabeshima T (2002). Role for brain-derived neurotrophic factor in learning and memory. Life Sci 70: 735-744.

Zhou J, Bradford HF, Stern GM (1994). The stimulatory effect of brain-derived neurotrophic factor on dopaminergic phenotype expression of embryonic rat cortical neurons in vitro. Brain Res Dev Brain Res 81: 318-324.

Zhou J, Bradford HF, Stern GM (1996). Induction of dopaminergic neurotransmitter phenotype in rat embryonic cerebrocortex by the synergistic action of neurotrophins and dopamine. Eur $J$ Neurosci 8: 2328-2339.

Zhou J, Pliego-Rivero B, Bradford HF, Stern GM, Jauniaux ER (1998). Induction of tyrosine hydroxylase gene expression in human foetal cerebral cortex. Neurosci Lett 252: 215-217. 